\title{
Clinical Results of Nitinol Plate Implantation for Reconstruction of Sternal Dehiscence
}

\author{
Tuba Apaydın, (1) Murat Akkuş
}

Thoracic Surgery Department,

University of Health Sciences, İstanbul Mehmet Akif Ersoy Thoracic and Cardiovascular Training and Research Hospital, İstanbul, Turkey

Submitted: 11.02.2020 Accepted: 23.09.2020

Correspondence: Tuba Apaydın SBÜ İstabul Mehmet Akif Ersoy Göğüs Kalp ve Damar Cerrahis Eğitim ve Araştırma Hastanesi, Göğüs Cerrahisi Anabilim Dalı, İstanbul, Turkey

E-mail: tubaapaydn72@gmail.com

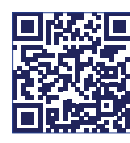

Keywords: Cardiac surgery; sternal dehiscence; sternum.

This work is licensed under a Creative Commons Attribution-NonCommercial 4.0 International License.

\begin{abstract}
Objective: Difficulties with sternal bone healing or infection after a median sternotomy performed for open cardiac surgery can result in significant morbidity and mortality. This study evaluates the efficacy, safety, advantages, disadvantages, and techniques related to the use of thermoreactive nitinol clips (TRNCs) to treat sternal dehiscence.
\end{abstract}

Methods: TRNCs were used to close the sternum in 40 patients ( 26 male, 14 female; mean age: $60 \pm 4$ years, range: $45-76$ years) with sternal dehiscence that developed following primary cardiac surgery between July 2010 and February 2019. Sternum revision was performed at a mean of $72 \pm 4$ days postoperative (range: 9-255 days). Vacuum-assisted closure (VAC) was applied before the surgical intervention in $55 \%(n=22)$ of the patients due to superficial wound infection.

Results: Pleurisy was observed in I patient, and pneumonia developed in I patient after the revision. Mortality did not occur during hospitalization. The nitinol plates were removed in a second revision surgery in 9 patients: a pectoralis flap was created for 3 , a reconstructive rectus flap was used in I, and primary wound closure was implemented in 5 cases due to recurrent wound infection. Mortality was recorded in I patient in the postoperative period. Sternotomy complications of recurrent sternal dehiscence, mediastinitis, sternal abscess, or secondary osteomyelitis were not observed in 6 months of follow-up.

Conclusion: Surgical interventions for sternal dehiscence should optimally be performed in the early period to decrease the risk of dehiscence secondary to infection and mediastinitis. The use of TRNCs for patients with sternal dehiscence was successful and decreased the duration of hospital stay and the risk of postoperative complications, as well as providing greater patient comfort.

\section{INTRODUCTION}

In 1957, Julian popularized the use of a median sternotomy to allow access to the intrathoracic organs, and this has been a lasting innovation in the field of cardiothoracic surgery. Although new cardiac operation techniques have emerged since, a traditional median sternotomy technique is still the most frequently applied procedure..$^{[l]}$ The prevalence of sternal wound infection and dehiscence after a median sternotomy has been reported to be $0.2 \%$ to $10 \%$ and the mortality rate has been recorded as $0.5 \%$ to $20 \% .{ }^{[2]}$

Typically, steel cerclage wires are used for a standard sternum closure. However, this technique may result in insufficient fixation and sternal dehiscence under a normal physiological load. ${ }^{[3]}$ Sternal dehiscence can develop as a result of mechanical injury following an asymmetric sternotomy incision. It can also be caused by sternal fractures that occur during the preparation of the internal mammary artery (IMA), force exerted on the sternum with a retractor during surgery, or problems related to the incision in the primary operation. ${ }^{[l]}$ Attacks of coughing, excessive activity, respiratory insufficiency, low cardiac output, and re-exploration due to bleeding increase the pressure over the sternum. This can cause chest wall discomfort and respiratory dysfunction, as well as superficial wound infection or mediastinitis. ${ }^{[1]}$

Risks for sternal dehiscence and infection are categorized in 3 groups. Preoperative risk factors include diabetes mellitus (DM), chronic obstructive pulmonary disease (COPD), renal insufficiency, tobacco use, and obesity. A prolonged coronary artery bypass graft (CABG) procedure is likely the most important risk factor. In addition, the need for a blood transfusion and prolonged mechanical ventilation add risk. ${ }^{[4]} \mathrm{A}$ misaligned sternum or an increased risk of cardiac perforation due to loose bone fragments or wires render sternal dehiscence a surgical emergency. ${ }^{[5]}$ 
A physical examination can reveal sensitivity, an audible click, oscillation of the sternum with a cough, or other chest wall movement. A plain chest radiograph may reveal early findings prior to clinical signs, however, a thorough review is required and not always performed. Minor abnormalities may include displacement or deterioration of sternal alignment as segments shift, and loss of central sternal lucency. Major findings of 2 or more wire dislocations are more dramatic and are rarely overlooked. ${ }^{[5]}$

Sternal dehiscence can be repaired using the classic or modified Robicsek technique, sternal plates, thermoreactive nitinol clips (TRNCs), or sternal talon systems. ${ }^{[I]}$ The objective of this study was to evaluate the effectiveness of the TRNC technique, and the risk factors and clinical results in cases of sternal dehiscence treated with a revision procedure after primary cardiac surgery.

\section{MATERIALS AND METHODS}

TRNCs were used in 40 patients with sternal dehiscence after primary cardiac surgery. Of the patients, 26 (65\%) were male and 14 (35\%) were female, with a mean age of $60 \pm 4$ years (range: $45-76$ years). In 22 cases, the surgical intervention was performed after vacuum-assisted closure (VAC) due to a surgical wound infection. The primary surgery was $C A B G$ in 30 patients, valve surgery in 8 patients, and ascending aorta replacement in 2 patients. Steel wires (Doğsan Surgical Sutures, Trabzon, Turkey) were used in the cardiac surgery. The preoperative risk factors (COPD, DM, renal insufficiency, bilateral IMA usage) are summarized in Table I. The preoperative, intraoperative, and postoperative data of all of the patients are presented in Table 2. The results of a preoperative wound culture performed before the revision, and other medical data were obtained retrospectively. Institutional ethical committee approval was obtained (2019/29).

Preoperatively, 10\% povidone iodine (Orbak Kimya, Istanbul, Turkey) solution was applied to the surgical area to prevent infection. Cefazolin (4 g/day) was administered in the postoperative period to patients with a negative wound culture until the chest drains were removed following cardiac surgery. Patients with an infected sternal wound were treated with antibiotherapy based on the surgical wound culture proliferation (Table 3). Antibiotherapy culture results were updated as data became available.

Sternal fixation was performed with 7 or 8 sternal wires applied in a single intervention. TRNCs were used to repair sternal dehiscence occurring after the initial surgery. The primary operation and perioperative details are summarized in Table 2.

\section{Surgical technique}

The sternum was explored with care given not to damage the internal thoracic arteries. The skin, subcutaneous tissue, and necrotic tissue around the sternum was debrided as needed to remove unviable tissue. The sternal wires were removed, as well as unviable bone and cartilage, in
Table I. Preoperative and intraoperative risk factors for sternal wound infections $(n=40)$

\begin{tabular}{lcc}
\hline & $\mathbf{n}$ & $\%$ \\
\hline Diabetes mellitus & 20 & 50 \\
Chronic obstructive pulmonary disease & 12 & 30 \\
Renal failure & 4 & 10 \\
Bilateral internal mammary artery & $\mathrm{I}$ & 2.5 \\
\hline
\end{tabular}

Table 2. Intraoperative and postoperative data related to the primary cardiac operation $(n=40)$

\begin{tabular}{lcc}
\hline & n & $\%$ \\
\hline *Intraoperative & & \\
Coronary artery bypass grafting & 30 & 75 \\
Valve & 5 & 12.5 \\
Ascending aorta replacement & 2 & 5 \\
Left internal mammary artery & 28 & 70 \\
Bilateral internal mammary artery & $\mathrm{I}$ & 2.5 \\
*Postoperative & & \\
Postoperative complications & & \\
Surgical wound infection & 22 & 55 \\
Pleurisy & 8 & 20 \\
Atrial fibrillation & 5 & 12.5 \\
Delirium & 2 & 5 \\
Pneumonia & 2 & 5 \\
Acute renal failure & 2 & 5 \\
Postperfusion syndrome & 2 & 5 \\
Mediastinitis & $\mathrm{I}$ & 2.5 \\
Pulmonary edema & $\mathrm{I}$ & 2.5 \\
Arrest & $\mathrm{I}$ & 2.5 \\
\hline
\end{tabular}

order to reach viable tissue. The intercostal area was perforated and loop clamps were applied to keep the sternum closed until the clips were attached. The distance between the intercostal spaces was measured from above and below the costochondral joint to determine the appropriate clip size after the 2 parts of the sternum were brought together. The clips used were 7-8 $\mathrm{mm}$ smaller than the measured distance. Nitinol clips composed of nickel and titanium are very flexible at low temperatures $\left(<8-10^{\circ} \mathrm{C}\right)$, and a shape memory effect begins with increased temperature $\left(27^{\circ} \mathrm{C}\right)$, with a final shape achieved at $35^{\circ} \mathrm{C}$. In this study, Jiangsu IAWA Biotech Engineering Co., Ltd. (Jiangsu, China.) nitinol alloy internal fixation devices were used (Fig. I). The clips were first cooled with ice and special forceps were used to facilitate localization in the intercostal space before the clip was heated with warm water to activate the shape-memory effect. This characteristic also allows for easy removal as necessary, as the clip does not integrate into the bone.

The TRNCs were placed horizontally in the intercostal space for simple fractures and transversely over the sternum in cases of a complicated fracture of the bilateral 
Table 3. Preoperative, intraoperative, and postoperative clinical data of the revision surgery $(n=40)$

\begin{tabular}{|c|c|c|c|c|}
\hline & $\mathbf{n}$ & $\%$ & Mean $\pm S D$ & Range \\
\hline \multicolumn{5}{|l|}{ *Preoperative } \\
\hline Time until revision (days) & & & $72 \pm 4$ & $9-255$ \\
\hline Sternal superficial wound infection (VAC treatment) & 22 & 55 & & \\
\hline Number of VAC applications & & & 3.4 & $|-| I$ \\
\hline Bacterial growth in wound & 17 & 42.5 & & \\
\hline Methicillin-resistant Staphylococcus aureus & 6 & 15 & & \\
\hline Methicillin-resistant coagulase negative Staphylococcus & 4 & 10 & & \\
\hline Klebsiella pneumoniae & 4 & 10 & & \\
\hline Pseudomonas aeruginosa & 1 & 2.5 & & \\
\hline Staphylococcus epidermidis & 1 & 2.5 & & \\
\hline Serratia & 1 & 2.5 & & \\
\hline C-reactive protein level (>5 $.0 \mathrm{mg} / \mathrm{dL})$ & 35 & 87.5 & & \\
\hline Leucocyte count $\left(>10.0^{*} 10^{9} / \mathrm{L}\right)$ & 13 & 32.5 & & \\
\hline \multicolumn{5}{|l|}{ Antibiotic usage } \\
\hline Cefazolin & 16 & 40 & & \\
\hline Piperacillin tazobactam & 9 & 22.5 & & \\
\hline Ampicillin sulbactam & 4 & 10 & & \\
\hline Ceftriaxone & 1 & 2.5 & & \\
\hline Moxifloxacin & 1 & 2.5 & & \\
\hline Ciprofloxacin & 1 & 2.5 & & \\
\hline Ertapenem & 2 & 5 & & \\
\hline Imipenem & & 1 & 2.5 & \\
\hline Meropenem & 1 & 2.5 & & \\
\hline Amikacin & 1 & 2.5 & & \\
\hline \multicolumn{5}{|l|}{ *Postoperative } \\
\hline Duration for extubation (minutes) & & & $259 \pm 55$ & $25-720$ \\
\hline Duration of hospitalization in intensive care unit & & & 0.72 & $0-3$ \\
\hline Duration of hospitalization & & & 10.2 & $3-23$ \\
\hline Complication & 2 & 5 & & \\
\hline Pleurisy & 1 & 2.5 & & \\
\hline Pneumonia & $\mathrm{I}$ & 2.5 & & \\
\hline Mortality & 0 & 0 & & \\
\hline *Revision $\left(2^{\text {nd }}\right)$ & 9 & 24.3 & & \\
\hline Pectoralis flap & 1 & 2.5 & & \\
\hline Rectus flap & 1 & 2.5 & & \\
\hline Primary wound closure & 5 & 12.5 & & \\
\hline Mortality & I & 2.5 & & \\
\hline
\end{tabular}

VAC: Vacuum-assisted closure; SD: Standard deviation.

edges of the sternum to provide greater stabilization (Fig. 2). The same procedure was used in the other intercostal spaces.

\section{RESULTS}

The preoperative and intraoperative risk factors for sternal wounds are summarized in Table I. Revision surgery was performed in all of the study patients for persistent dehiscence. Preoperative and intraoperative data are presented in Table 2 and Table 3. Patients with dehiscence underwent TRNC surgery for sternal revision at a mean of primary postoperative 72 \pm 4 days (range: 9-255 days). Sev- en intubated patients were in the intensive care unit for I day. VAC was performed prior to the revision due to sternal wound infection in 22 patients (55\%). An average of 3.4 (range: I-II) VAC applications was used in these cases. Bacterial growth in a wound culture was positive in 17 patients (42.5\%). Methicillin-resistant Staphylococcus aureus (MRSA) developed in 6 patients (15\%), Methicillin-resistant coagulase-negative Staphylococcus (MRKNAS) in 4 (10\%), Klebsiella pneumoniae in 4 (10\%), Pseudomonas aeruginosa in I (2.5\%) and a Serratia infection in I (2.5\%). The C-reactive protein level (87.5\%) was positive in 35 patients $(>5.0 \mathrm{mg} / \mathrm{dL})$. The leukocyte count was high in 13 patients $(32.5 \%)\left(>10.0 \times 10^{\%} / \mathrm{L}\right)$. Cefazolin was admin- 


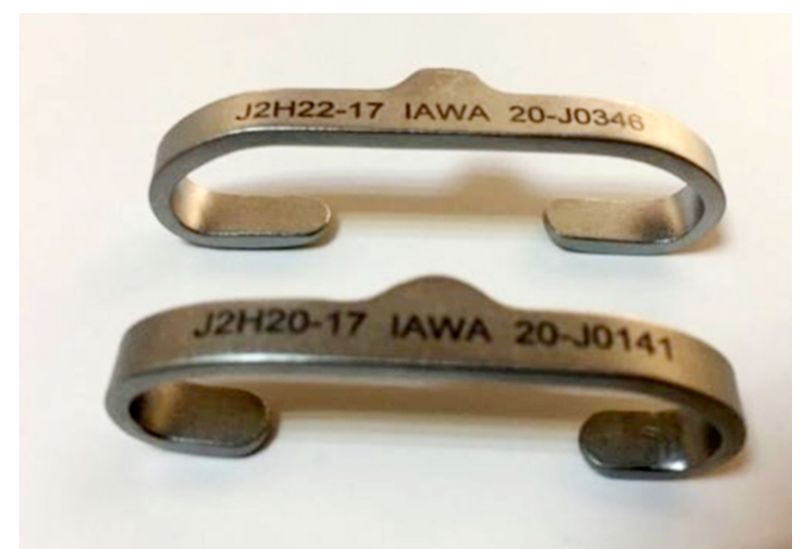

Figure 1. Thermoreactive nitinol clips.

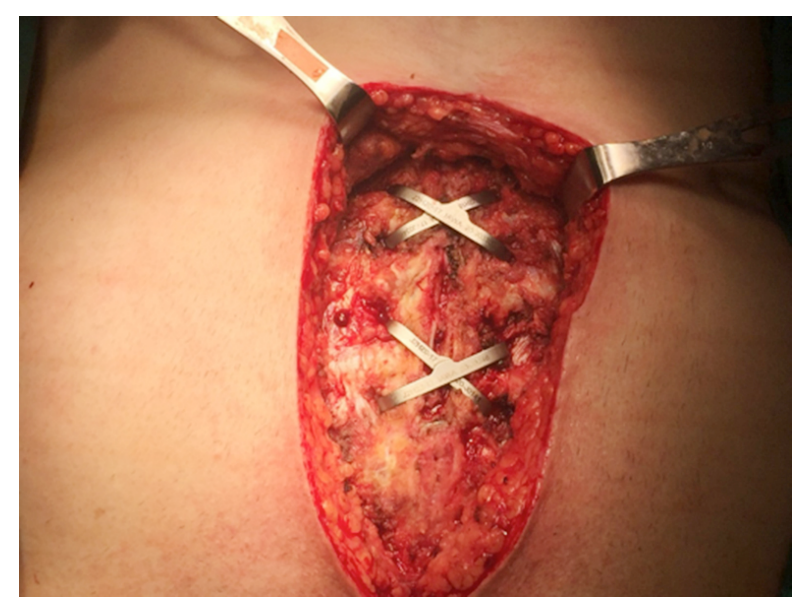

Figure 2. Clips placed crosswise over the sternum for complicated fractures.

istered preoperatively in 16 patients (40\%), while piperacillin tazobactam was used in 9 patients $(22.5 \%)$, and ampicillin sulbactam in 4 patients (10\%) (Table 3). The mean duration of extubation was $259 \pm 55$ hours (range: $25-720$ hours). The length of hospitalization in the intensive care unit was a mean of 0.72 days (range: $0-3$ days). The duration of hospitalization was a mean of 10.2 days (range: 3-23 days). A postoperative complication was observed in 2 patients (5\%): pleurisy in I patient $(2.5 \%)$ and pneumonia in I patient (2.5\%) (Table 3). In the second revision surgery, the nitinol plates were removed in 9 patients: a pectoralis flap was used in 3 cases, a reconstructive rectus flap in I, and primary wound closure was performed in 5 cases with a recurrent wound infection following a negative report of bacterial growth in a wound culture. Mortality was observed in I patient due to respiratory insufficiency in the seventh postoperative month after the second revision surgery.

\section{DISCUSSION}

The median sternotomy technique first described by Minton in 1887 offered the means for a more complete exploration of the heart and mediastinal components in open cardiac surgery. However, sternal dehiscence and wound infection continue to be significant complications of this procedure. ${ }^{[3]}$ The diagnosis is generally made radiologically. Displacement of sternal wires and a midsternal stripe are the most common radiological manifestations. Sternal dehiscence that is not due to infection typically presents with sternal separation, chest wall discomfort, and respiratory difficulty. ${ }^{[6,7]}$ Although the reported incidence of sternal dehiscence is only $0.4 \%$ to $5.1 \%$, the resulting morbidity and mortality rate is high. ${ }^{[3]}$

The development of sternal dehiscence after a sternotomy for CABG, valve operation, or other thoracic surgery has long been a problematic complication. ${ }^{[2]}$ In this study, the primary operation was CABG in $75 \%$ and valve surgery in $12.5 \%$.

The traditional method of using sternal wires remains a frequently used means to achieve sternal closure. The low cost, education, and the low rate of sternal wound complications are among the reasons this method continues to be preferred. However, randomized data demonstrate that rigid plate fixation provides better bone healing than sternal wires. Raman et al. ${ }^{[8]}$ reported less use of analgesics in the early postoperative period after rigid plate fixation. Delay in bone healing can disrupt recovery, respiratory function, and activity. ${ }^{[9-11]}$ In this study, $75.7 \%$ of the patients who had sternal dehiscence following the use of sternal wires were successfully treated with TRNCs. The remaining $24.3 \%$ of the study patients were treated with a second revision surgery due to recurrent wound infection.

Patients with a thin and fragile sternum are more prone to have sternal dehiscence after open cardiac surgery. ${ }^{[6]}$ Bone stability is of particular importance in patients with DM, renal failure, COPD, or diminished lung volume. ${ }^{[4]}$ In our study, $50 \%$ of patients with sternal dehiscence after cardiac surgery had DM, 30\% had COPD, and renal failure was a predisposing factor in $10 \%$. Sternal wiring was unsuccessful in the primary operation because the bones were fragile and there were multiple fractures.

Various surgical methods, such as the use of TRNCs, talon systems, sternal plates, the Robicsek technique, and muscle flaps can be a sternal dehiscence in many centers. ${ }^{[1-3]}$ There is no consensus on a standard, preferred technique. Sarıkaya et al. ${ }^{[12]}$ compared the Robicsek technique and TRNCs. They reported similar complication rates $(6.3 \%$ for the Robicsek technique and 7.7\% for TRNCs). However, Bejko et al. ${ }^{[13]}$ reported a better dehiscence ratio when they used TRNCs than with standard sternal wiring (SSW) (0\% and $1.6 \%$ need for rewiring for TRNCs and SSW, respectively). ${ }^{[10,11]}$ No sternal dehiscence was observed following the application of TRNCs in patients with sternal dehiscence in that study.

TRNCs, composed of a nitinol alloy, have significant advantages when compared with titanium plates, which are made of stainless steel, as they are less destructive, more biocompatible, and stable. ${ }^{[6]}$ Their thermoreactive structure enables easy and safe application to the bone. Nitinol clips don't integrate with bone and are more compatible 
with magnetic resonance imaging computed tomography scans. ${ }^{[13,14]}$ The risk of bleeding is also lower than with standard wires. Nitinol clips provide up to $15 \%$ elasticity under tension. At body temperature, the rigidity of the clips can cause fractures with high force, however, force also causes fractures when wires are used. The risk of torsion of the bone is lower with clips because they have a larger surface area. These advantages and reports in the literature led us to choose nitinol clips for our patients. ${ }^{[1-6]}$

Debridement and closure with a muscle flap was preferred in cases of a sternal wound infection. High vacuum pressure with polyurethane foam provided effective treatment of infection developing after the median sternotomy. However, this technique can only be used in patients with intact pleura, and has potential complications of a cardiac output decline and pleural rupture. ${ }^{[2]}$ Reiss et al. preferred TRNCs for the repairment of sternal dehiscence after sternal VAC. They applied this technique without dissecting the adhesions in the substernal area and no complication was reported. $\left.{ }^{[}\right]$

Of the patients in this study, $55 \%$ had wound culture positivity in the sternal wound before revision. Wound cultures identified MRSA as the most common agent, followed by MRKNAS and Klebsiella pneumoniae. In our study, VAC was performed due to superficial wound infection before TRNC application in $55 \%$ of the patients. We did not dissect the adhesions in the substernal area regarding the risk of cardiac injury and no postoperative complication was observed in this patient group. The nitinol plates of $9 \mathrm{pa}-$ tients were removed in the postoperative period due to recurrent wound infection.

Olbrecht et al. reported a rate of sternal dehiscence of $20 \%$ using classic methods, such as the Robicsek technique, with or without a muscle flap for sternal dehiscence and wound infection. ${ }^{[3]}$ In this study, the nitinol plates were removed in 9 cases: a pectoralis flap was used in 3, a reconstructive rectus flap was created in I case, and primary wound closure was performed on 5 patients due to recurrent wound infection. No sternal dehiscence was found in the postoperative period.

Nikolaidis et al. ${ }^{[15]}$ reported that the incidence of sternal wound infection was lower with TRNCs compared with SSW after sternal closure (I.7\% vs $2.3 \%) .^{[16,17]}$ Sarıkaya et al. ${ }^{[l]}$ preferred to use TRNCs and found them to be beneficial to prevent infection. Similarly, Bejko et al. found less deep sternal wound infection after the application of TRNCs compared with SSW $(0.2 \%$ vs $1.6 \%$; $p=0.02)$. [15-19] They compared 1702 patients who had undergone a procedure with SSW and 572 patients with TRNCs and concluded that TRNCs were superior to SSW for sternal closure. In our study, $24.3 \%$ of the patients experienced a sternal wound infection after the application of TRNCs and $59.4 \%$ developed a sternal wound infection following the use of SSW.

Titanium reconstruction plates, cables, and screws may extend the lateral area for fixation via horizontal rib-to- rib stabilization, however, we did not elect to use these techniques in patients with poor bone quality. Of our patients, $50 \%$ had DM and $30 \%$ had COPD in the preoperative period. TRNCs were effective in our patients with mild osteoporosis. ${ }^{[20]}$

Postoperative sternal dehiscence may be observed during the initial hospitalization period. ${ }^{[1]}$ Early surgical intervention should be considered to avoid the risk of mediastinitis. However, sternal dehiscence was only discerned I month postoperatively in $55 \%$ of our patients and the mean time until revision was $72 \pm 4$ days, which was related to the fact that $30 \%$ of our patients were referred to us from other clinics. No mediastinitis complication of revision was seen.

The mean postoperative hospitalization period after revision for our patients was 10.2 days. The mean period for extubation was $259 \pm 55$ minutes. The mean postoperative length of stay in the intensive care unit was 0.72 days. We found that the use of TRNCs to correct sternal dehiscence provided a satisfactory recovery.

\section{CONCLUSION}

TRNCs can be a practical means to provide bone stabilization and preservation of functional movement of the sternum. We found TRNCs to be very satisfactory even in patients with a thin and fragile sternum due to comorbidity factors. We suggest the use of TRNCs without substernal tissue dissection to treat sternal dehiscence after sternotomy with or without wound infection. TRNCs are a safe, quick, and easy option that requires less hospitalization and has a lower cost.

Funding

This research received no specific grant from any funding agency in the public, commercial, or not-for-profit sectors.

Ethics Committee Approval

Approved by the İstanbul Mehmet Akif Ersoy Thoracic and Cardiovascular Training and Research Hospital Ethics Committee (2019/29).

Peer-review

Internally peer-reviewed.

Authorship Contributions

Concept: T.A., M.A.; Design: T.A., M.A.; Supervision: T.A., M.A.; Fundings: T.A., M.A.; Materials: T.A., M.A.; Data: T.A., M.A.; Analysis: T.A., M.A.; Literature search: T.A., M.A.; Writing: T.A., M.A.; Critical revision: T.A., M.A.

Conflict of Interest

None declared.

\section{REFERENCES}

1. Sarıkaya S, Büyükbayrak F, Altaş Ö, Yerlikhan O, Fedakar A, Rabuş M, et al. Thermoreactive nitinol clips for re-sternotomy in cases of sternal dehiscence. Turk Gogus Kalp Dama 2013;21:669-75. [CrossRef]

2. Sahasrabudhe P, Jagtap R, Waykole P, Panse N, Bhargava P, Patwardhan $\mathrm{S}$. Our experience with pectoralis major flap for manage- 
ment of sternal dehiscence: a review of 25 cases. Indian J Plast Surg 2011;44:405-13. [CrossRef]

3. Fawzy H, Osei-Tutu K, Errett L, Latter D, Bonneau D, Musgrave M, et al. Sternal plate fixation for sternal wound reconstruction: initial experience (Retrospective study). J Cardiothorac Surg 2011;6:63. [CrossRef]

4. Karaca K, Mavioğlu, Karaca K. Açık kalp cerrahisi sonrasında gelişen sternal dehisensin titanyum mesh ile onarım. Turkiye Klinikleri J Cardiovasc Sci 2008;20:222-4.

5. Gad M, Gupta A. Dancing sternal wires: a radiologic sign of sternal dehiscence. Clevel Clin J Med 2019;86:87-8. [CrossRef]

6. Gucu A, Toktaş F, Eriş C, Ata Y, Turk T. Nitinol thermoreactive clips for secondary sternal closure in cases of noninfective sternal dehiscence. Tex Heart Inst J 2012;39;513-6.

7. Hayward RH, Knight WL, Baisden CE, Reiter CG. Sternal dehiscence. J Thorac Cardiovasc Surg 1994;108:616-9. [CrossRef]

8. Raman J, Lehmann S, Zehr K, Guzman B.J.D, Aklog L, Garrett E, et al. Sternal closure with rigid plate fixation versus wire closure: a randomized controlled multicenter trial. Ann Thorac Surg 2012;94:1854-61. [CrossRef]

9. Eisenberg E, Pultorak Y, Pud D, Bar-El Y. Prevalence and characteristics of post coronary artery by pass graft surgery pain. Pain 2001;92:11-7. [CrossRef]

10. Kalso E, Mennander S, Tasmuth T, Nilsson E. Chronic post sternotomy pain. Acta Anaethesiol Scand 2001;45:935-9. [CrossRef]

11. Taillefer MC, Carrier M, Bélisle S, Levesque S, Lanctôt H, Boisvert $\mathrm{AM}$, et al. Prevalence, characteristics and predictors of chronic nonanginal postoperative pain after cardiac operation: a cross sectional study. J Thoracic Cardiovasc Surg 2006;131:1274-80. [CrossRef]

12. Sarıkaya S, Aksoy E, Özen Y, Dedemoğlu M, Özgür MM, Büyükbayrak F, et al. Thermoreactive nitinol clips: propensity score com- parison with Robicsek technique. Asian Cardiovasc Thorac Ann 2015;23;399-405. [CrossRef]

13. Bejko J, Bottio T, Tarzia V, De Franceschi M, Bianco R, Gallo M, et al. Nitinol flexigrip sternal closure system and standard sternal steel rewiring: insight from a matched comparative analysis. J Cardiovasc Med (Hagerstown) 2015;16:134-8. [CrossRef]

14. Şahin M, El H, Mert FTİ. Comparison of three different sternal closure techniques after cardiac surgery in elderly patients. J Surg Med 2018;:205-9. [CrossRef]

15. Nikolaidis N, Karangelis D, Mattam K, Tsang G, Ohri S. The use of Nitinol clips for primary sternal closure in cardiac surgery. Ann Thorac Cardiovasc Surg 2013;19:330-4. [CrossRef]

16. Careaga Reyna G, Aquirre Baca GG, Medina Concebida LE, Borrayo Sánchez G, Prado Villegas G, Argüero Sánchez R. Risk factors for mediastinitis and sternal dehiscence after cardiac surgery. Rev Esp Cardiol 2006;59:130-5. [CrossRef]

17. Olbrecht VA, Barreiro CJ, Bonde PN, Williams JA, Baumgartner WA, Gott VL, et al. Clinical outcomes of noninfectious sternal dehiscence after median sternotomy. Ann Thorac Surg 2006;82:902-8.

18. Atay M, Toz H, Açıkgöz B, Türkyılmaz S, Kavala AA. Application of titanium plate fixation in sternal dehiscence after cardiac surgery. Am J Card 2018;121:26-7. [CrossRef]

19. Tewarie LS, Menon AK, Hatam N, Amerini A, Moza AK, Autschbach R, et al. Prevention of sternal dehiscence with the Sternum External Fixation (Stern-E-Fix) corset--a randomized trial in 750 patients. J Cardiothorac Surg 2012;7:85. [CrossRef]

20. Cataneo DC, Reis TA, Felisberto G, Rodrigues OR, Cataneo AJM. New sternal methods versus the standard closure method: systematic review and meta-analysis. Interact Cardiovasc Thorac Surg 2019;28:432-40. [CrossRef]

\section{Sternal Dehisens Onarımında Nitinol Plak Kullanımının Klinik Sonuçları}

Amaç: Açık kalp cerrahisinde uygulanan median sternotomi sonrasında sternal kemik iyileşmesi ve enfeksiyon problemleri önemli morbidite ve mortalite ile sonuçlanabilmektedir. Bu çalışma ile sternal dehisens için uygulanan termoreaktif nitinol klipslerin (TRNK) etkinliğini, güvenilirliğini, avantajlarını, dezavantajlarını ve tekniklerini değerlendirmeyi amaçladık.

Gereç ve Yöntem: Temmuz 2010'dan Şubat 2019'a kadar; kliniğimizde primer kalp cerrahisi sonrası sternal dehisens gelişen 40 hastaya

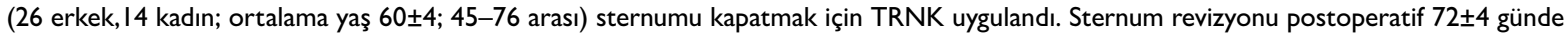
(9-255 gün) uygulandı. Hastaların \%55'inde $(n=22)$ yüzeyel yara enfeksiyonu gelişmesi nedeniyle vakum yardımlı kapama (VAK) tedavisi sonrası cerrahi müdahale uygulandı.

Bulgular: Revizyon sonrası bir hastada plörezi, bir hastada pnömoni gelişti. Hastane mortalitesi gözlenmedi. İkinci revizyon cerrahisinde, nükseden yara yeri enfeksiyonundan dolayı; nitinol plaklar dokuz hastada çıkartıldı, üç hastaya pektoral flap uygulandı, bir hastaya rektus flap uygulandı; beş hastada da yara primer kapatıldı. Ameliyat sonrası dönemde bir hastada mortalite gözlendi. Altı aylık takipte nükseden sternal dehisens, mediastinit, sternal apse ya da sekonder osteomyelit gibi sternotomi komplikasyonları izlenmedi.

Sonuç: Sternal dehisens olgularında enfeksiyona sekonder dehisens gelişimi ve buna bağlı mediastinit riskini azaltmak için erken dönemde cerrahi müdahaleler uygulanmalıdır. TRNK'nin sternal dehisensli hastaların tedavisi için hastanede kalma süresini ve ameliyat sonrası komplikasyon riskini azaltmada ve hasta konforunu artırmada kullanılmasını öneriyoruz.

Anahtar Sözcükler: Kalp cerrahisi; sternal dehisens; sternum. 